\title{
Sosialisasi, Street Vendors and Citizenship in Yogyakarta
}

\author{
Sheri Lynn Gibbings
}

In 2006 and 2007, Pethikbumi (Pedagang Klithikan Mangkubumi), a group of street traders ${ }^{1}$ slated to be relocated to a newly renovated marketplace in Yogyakarta City, Indonesia, argued in government meetings and in the newspaper that the relocation plan was not clear (kurang jelas). The Kedaulatan Rakyat newspaper reported that 'the leader of Pethikbumi, Akbar, said the concept developed by the municipal government regarding the relocation was not transparent (tidak transparan), especially with money.... "I also have asked for a detailed relocation concept but I haven't been given it,' said Akbar." In the months leading up to the relocation deadline of November 2007, Pethikbumi publically critiqued the municipal government's lack of proper sosialisasi (socialization) regarding its plans to relocate hundreds of traders to a marketplace through letters to the government, newspaper articles and public and private meetings.

Proposed by then-mayor of Yogyakarta City, Herry Zudianto, the klithikan (second-hand trader) relocation would move street vendors from three locations in the city to a renovated former animal marketplace, Kuncen. The traders would gain clear legal status and be empowered to develop their businesses. $^{3}$ The new marketplace was also pegged to become a tourist attraction because it would bring together in one location a variety of traders selling second-hand and antique merchandise (Pethikbumi meeting, personal communication, January 16,2006 ). With this plan, the municipal government of Yogyakarta intended to follow the example of the mayor of Solo (now governor of Jakarta), Joko Widodo, who had 'successfully' relocated klithikan traders in

1 Street traders are referred to as pedagang kaki lima ( $\mathrm{PKL})$ in Bahasa Indonesia. In the paper I use the terms street traders and street vendors interchangeably.

2 'Konsep Pasar Klithikan Dinilai Kurang Jelas: Tolak Relokasi, Pethikbumi Datangi Dewan' Kedaulatan Rakyat, March 16, 2007.

3 These statements are still used by the municipal government in the production of information about Kuncen marketplace. A book profiling the different marketplaces in Yogyakarta says that the relocation was a successful attempt by the government to better the lives of the people (traders), despite the conflict between the pro and contra traders (Dinas Pasar Yogyakarta 2013:31). 
2006 without violence (Sinombor 208). ${ }^{4}$ As in Solo, the klithikan relocation in Yogyakarta was considered a generous gesture by the municipal government because the traders were offered an indoor location for free, financial support as well as training during the transition period.

The municipal government of Yogyakarta publicly promoted the idea that they were 'dialoging' (consulting) with Pethikbumi traders in 2007. However, the details of the project and plan had already been under discussion for years, mostly without the traders' involvement. ${ }^{5}$ In 2004 and 2005, the government conducted a series of confidential and undisclosed surveys, analysing the impact on the surrounding community, traders and land. The Impact Control Office (Kantor Pengendalian Dampak) produced the Kuncen Market Development Plan (Pemerintah Kota Yogyakarta) in 2004 and consultants employed by the government produced two of the other reports written in 2005 (see CV. AKA and PT. CIPT Nindita Buana). These reports provided support for the relocation and outlined the potential effects this would have on various communities such as the surrounding neighbourhoods, traders and parking agents.

Almost all of these reports recognized that there might be resistance to the relocation. The solution to this problem was 'socialization' (sosialisasi), which meant talking to the different groups about the programme, including the street vendors and surrounding communities ('Rencana Pembangunan Pasar Kuncen' 2004). In 2005, the government started discussions with several of the Pethikbumi traders, and took them on a comparative study trip to Bandung, a city in West Java ('Polemik Klithikan' 2006). Yet the majority of the traders remained in the dark about the relocation plans and in October 2006 a number of traders accused Pethikbumi's leaders of taking bribes to accept the relocation ('Polemik Klithikan,' 2006). At this point, a new group of traders took control of Pethikbumi and demanded that they see a written relocation plan (konsep relokasi).

This chapter discusses the changing nature of citizenship in Indonesia since the political transition in Indonesia (Reformasi), through the case study of the government relocation of street vendors to Kuncen Marketplace. I focus on the term sosialisasi because surprisingly little attention has been given to this term and its practices in academic literature on Indonesia, yet it is commonly used to describe practices of consultation and communication across the

4 The newspaper article stated, 'For six months Jokowi and Hadi Rudyatmo invited the sellers to dialogue. If we want quick and easy, we could. With our authority, we could just turn up with a bulldozer, clear, and be finished'. (Sinombor 2008).

5 A leader from the Aseme Gede group did receive information about a possible relocation in 2004, but this information was not widely circulated ('Gugatan TUN' 2007). 
Indonesian archipelago. The fact that sosialisasi was used so frequently during the New Order as part of Suharto's Festival of Democracy (Pemberton 1994) also raises questions as to what extent the meanings and practices of sosialisasi are changing in the current era.

In the New Order intepretation sosialisasi is a process in which the government (or another top-down institution) teaches/persuades another group (generally a less powerful or more 'ignorant' group) to follow a prescribed viewpoint/set of behaviours. The current municipal government continues to view it this way. In the case of the relocation, civil servants perceived sosialisasi as a process through which the vendors are persuaded that the relocation is in their best interests. However, when Pethikbumi claimed the government did not sufficiently 'socialize' the vendors about the relocation, they were not using the term in the same sense. The vendors understand socialization to mean something different: the provision of transparent and detailed plans about the relocation, an open and meaningful consultation in order to reach a mutual agreement about a relocation plan that addresses the vendors' concerns.

I argue that in order to understand changes in citizenship in Indonesia we must chart and understand the words and practices through which claims are made. I show how the New Order term sosialisasi is taken up by street vendors, a largely illegal and marginal group, as a means to claim their rights. Especially since Reformasi, traders have gained support from civil society groups (NGOS, legal aid organizations, and student groups) that are helping them make claims for their rights. In order to understand citizenship we must situate its practices in local discourses, networks and politics (cf. Humphrey 2004:433). I illustrate how there are certain habits and discourses of sociality, namely sosialisasi, that are being carried forward and challenged in post-Suharto Indonesia.

\section{Citizenship and Street Vendors: A Changing Landscape}

Anthropologists working on citizenship have noted that while by law people might have equal rights, in practice many inhabitants of a state cannot realize these rights (Chatterjee 2004; Holston 2008; Ong 1999). James Holston (2008:7), for instance, illustrates that Brazil is characterized by a form of 'differentiated citizenship' which is 'universally inclusive in membership and massively inegalitarian in distribution'. In India, Partha Chatterjee (2004:40) describes how many illegal and marginalized groups have pressured the government to provide them with assistance and entitlements through patron - client networks and their strategic use of the vote. He argues that these marginal citizens are excluded from civil society, the domain of 'proper' citizens, and are instead 
part of what he calls 'political society'. Akil Gupta (2012:99) similarly argues that citizenship has a different meaning in the postcolonial context because it is not always 'imbricated with the emergence of civil society'.

In the Indonesian case, the concept of rights almost always appears with the term responsibility or duty (hak dan kewajiban). During the New Order, the rights of individual citizens were seen as subservient to the interests of the collective. Under Suharto, the government often claimed that freedom of expression should be curtailed for the sake of maintaining national unity, political stability and economic development. In the post-Suharto period, discussion of rights as relating to collective responsibilities has continued. In the Jakarta Post an opinion piece states, 'Citizenship implies not only individual rights but responsibilities toward the group. The concept of the civil society means learning to consider the needs of the group and of fellow citizens. For every right there is a corresponding responsibility' ('Education' 1999). I often heard ideas like this during my fieldwork. The traders would argue that they had certain rights but that they also had many responsibilities to fulfil such as keeping the street clean, safe and orderly.

In addition to citizenship meaning different things to different people in Indonesia, numerous groups compete over the authority to oversee citizenship claims. In Indonesia, power is comprised of a patchwork of competing authorities involving a mixture of state and non-state actors (Barker and Van Klinken 2009). ${ }^{6}$ Gangs, vigilantes and private security commonly lay claim to the kinds of authority traditionally monopolized by the state (cf. Barker 1998, 2006, 2009; Hansen and Stepputat 2001). Christian Lund (2011:888) argues that different institutions compete to define and enforce rules, and in effect secure recognition as the actors who have the right to provide 'rights' to others. He concludes that we must not only examine the rights people have, but also the various institutions that guarantee and protect these.

In Indonesia there have been a number of different actorsinterested in controlling where and how street vendors operate. During the colonial period, street sellers (pedagang) often travelled door-to-door selling fruits, vegetables, and other goods and services. The colonial government was concerned with containing these traders, and as a result urban planners such as Thomas Karsten built marketplaces in cities across Java to do just that (Jessup 1985; Kusno 2005). Immediately after independence, street trading increased as vendors provided the native population with access to cheap merchandise and food (Jellinek 1991). Like its predecessors, however, this new Indonesian

6 I do not see the state as a singular entity; similar to Akil Gupta (2012:55) I view it as 'historically contingent, incomplete, and perhaps even tenuous.' 
government was concerned with creating cities that were 'modern'. As street vendors were considered part of what made the city and street appear 'unmodern', traders needed to be relocated and contained in a marketplace (Kusno 2005).

During the Suharto years (1965-1998), a patchwork of competing authorities sought to control the rights of street traders. After Suharto came to power, street vendors started to occupy sidewalks in more permanent ways; by the 1970 and 8os, many set up kiosks and began to 'own' a certain square meter of the sidewalk. Some traders managed to negotiate their rights to the street temporarily at least in exchange for supporting Suharto's political party, Golkar (Dody, personal communication, June 2007). ${ }^{7}$ Others managed to obtain rights to the street by informally paying fees to the military, gangsters, or Golkar's security group Pemuda Pancasila for protection. The traders did not have the formal right to sell on the street, but were able to do so because of the cultivation of informal relations that allowed them to circumvent state policies. In particular instances, the municipal authorities extended rights to traders on an exceptional basis, without jeopardizing the overall idea that vending did not belong on the street but in marketplaces (cf. Chatterjee 2004). The 1970s and 8 os were thus marked by an 'entire substructure of paralegal arrangements' created or at least recognized by governmental authorities. These paralegal arrangements were not necessarily viewed as legitimate by society, but were also not frowned upon as much as other activities such as corruption (cf. Aspinall and Van Klinken 2011).

In the 1970 s and 8os, the growing number of 'permanent' street traders and their increasing power to control the street made them an important topic of study for academics and policymakers in Indonesia (Hammado 1979; Ichsan 1982; Waworoentoe 1975). The majority of these reports concluded that government policy was inconsistent toward traders, and that traders were engaged in different types of illegal exchanges in order to secure their right to the street. There was also a growing fear that street vendors needed to be controlled, monitored and generally looked after because otherwise they could turn violent (Masalah Pedagang 1980). The mayors in cities across Indonesia, typically appointed military personnel, continued the practice of trying to relocate

7 In 1981, some street vendors in Yogyakarta formed an organization called PPJ-Y (Persatuan Pedagang Pinggir Jalan Yogyakarta, or Yogyakarta Roadside Traders Union). The main goals at the time were to promote devotion (pengabdian), solidarity (solidaritas) and nationalism (kerakyatan), all aligned with Pancasila, the state philosophy (Bangun 1994). Kosgoro, with strong Golkar affiliations, helped form Tri Dharma (Dody, personal communication, June 2007). 
traders to marketplaces in order to achieve Suharto's central goals of cleanliness (keberishan) and order (ketertiban).

After the fall of the New Order in 1998, the constellation of rights and responsibilities began to shift because of two simultaneous processes: decentralization and democratization (Aspinall 2013; Telle 2009). Democratization has enabled civil society to grow stronger (Ford 2009; Hadiwinata 2004). Yet criminal elements have succeeded in creating spaces for themselves (Ryter 2009; Aspinall and Weiss 2012). ${ }^{8}$ As a result, there are now even more actors competing for control over territories and resources. In addition, decentralization has caused local urban politics to have become more important, as power has shifted from the capital to local governments (Reerink 2009; Schulte Nordholt 2003).

Under growing pressure to increase revenues, collecting taxes from street vendors or new market traders has become an important income-generating strategy (Gibbings 2013; Reerink 2009). As municipalities try to capture the incomes of street traders by relocating them to marketplaces or through issuing temporary permits, NGOS and street vendor organizations are trying to convince authorities to treat traders and their organizations as legitimate members of civil society. As such, municipal governments are under increasing pressure from the public, civil society groups and international actors to use sosialisasi rather than forcibly evicting traders ('Satpol PP' 2012). Growing numbers of trader organizations have sought support from legal aid organizations, NGOS, and community organizations to help protect their interests, and to pressure municipal governments to listen to their concerns. When traders were being evicted in South Jakarta, several organizations (including the Indonesian Environmental Forum (Walhi), the Jakarta Legal Aid Institute and several university student bodies) supported the vendors by coming to the area to document any violence used against them ('Traders Brace' 2008).

Along with this pressure to 'dialogue' with traders through socialization, municipal governments have had more power to develop their own city-specific regulations on street vending (Reerink 2009). Almost every municipality has developed its own street vendor regulations (Dipa 2012). Many of these new regulations outline the rights of traders to the street, but also their responsibilities to maintain its cleanliness and security. In 2002, the mayor of Yogyakarta created a new regulation on street vending (Regulation No. 26 2002), which required every street vendor to obtain a permit from the government, pay a

8 Edward Aspinall and Meredith L. Weiss (2012:214) argue that in the 1990s, donor governments focused their attention toward supporting civil society groups. See their chapter for a history of civil society in Indonesia and Malaysia. 
tax, and hold an identity card (BPH K, personal communication, 12 December 2007)..$^{9}$ Despite this regulation, the majority of traders in Yogyakarta City did not acquire such a permit. Out of the 5,525 street vendors in fourteen districts of the city, only 837 had permits in 2005 (РT. СIPT Nindita Buana 2005). Most municipal government officials in Yogyakarta remain concerned that giving too many rights to traders will give street trading legitimacy. For example, officials would often complain that traders along Malioboro Street, a main street of the city, were too powerful and relocating them would be a nearly impossible task, particularly as there were concerns that other groups could reproduce these same power structures, resulting in the need to continuously evict vendors.

However, high-ranking individuals have also started to support the idea of empowering traders rather than evicting them. President Susilo Bambang Yudhoyono passed a Presidential Regulation (Perpres) about the organization and 'empowerment' of street vendors (Number 125 212) (Massa 2013). In March 2012, he argued that street vendors were beneficial to regions because 'poverty is reduced, also criminality in cities is reduced' (Liu 2012). Likewise, the coordinating minister for Economic Affairs, Hatta Rajasa, has become a member of the Honorary Board of the Indonesian Street Vendor Association (APKLI) and has declared his commitment to help protect (melindungi) street traders (Rajasa 2013). Joko Widodo, the president of Indonesia, has also become renowned for his 'humane' treatment of street vendors which is widely discussed in newspapers, and on Twitter and Facebook (Afifah 2012). However, like other leaders, Joko still believed that street vendors should be relocated to the marketplace, albeit in a compassionate and participatory manner (Dwi 2013). Generally traders see these changes as part of competitive electoral mobilization of the poor. Democratic political competition has enabled street vendors to look for alternative support in case a leader or party is not willing to support them. Authors such as Deasy Simandjuntak (2012) have described this as 'patronage democracy' and have noted that in this configuration clients do have gained more power vis-ntak (2012) have desc.

All these developments are changing the attitudes of street vendors. Since 1998, there has been a surge in the activities and visibility of civil society and their support of street traders especially during moments of eviction or

9 This legislation signified an attempt to shift authority from the street vendor organizations and the community back into the hands of the government. As a result, more than fifteen trader organizations across the city voiced their concern that they were being excluded as key actors, and that the trader organizations should provide recommendations regarding the permits (personal communication, 12 December 2007). 
relocation. The government is likewise ramping up its strategies to transfer and capture the incomes of traders to increase their revenues. Organized street vendor groups, with the help of legal aid organizations, NGOS and university student groups, demand that the concerns of the traders must be heard and addressed as citizens. Although traders are still in the business of striking deals with the police, criminal gangs, and political parties, I will illustrate that they are also simultaneously being incorporated into the realm of middle-class activism. I will first, however, describe the history of the term sosialisasi and how it is being used today.

\section{Sosialisasi: A Legacy of the New Order?}

During the New Order period, the state tightly controlled what information was available to its citizens. Tough restrictions and legislation to control the press were instituted (Hill 2006). During this era, instructions or orders were given primarily through community meetings with minimal recordkeeping, and this process was called sosialisasi. The term referred to the process of sharing information and gaining acceptance for new plans or regulations. After the fall of the New Order, the term continued to be used to suggest the sharing of information through face-to-face communication (Lazuardi, personal communication, 21 November 2013) $\cdot{ }^{10}$ One standard textbook used in middle schools claims, 'sosialisasi is a process of transferring values and norms through agents, actions, and patterns' (Maryati and Suryawati 2006:105). The agents of socialization in this context are described as the students' parents, peer group, school, and the media. Socialization can be 'repressive' (represif) or 'participatory' (partisipatoris). Repressive sosialisasi is when the law is used to penalize errors, and is described as one-way communication such as obedience to one's parents. Participatory sosialisasi is described as a pattern when children are symbolically rewarded or penalized for their behaviour. This participatory socialization process gives children more freedom, and emphasis is placed on verbal interaction and communication (Maryati and Suryawati 2006:109). ${ }^{11}$

The origins of sociology are closely connected to concerns over 'social control' and the idea that a society should regulate itself (Janowitz 1975:82). It is thus not surprising that the Indonesian government borrowed this sociological

\footnotetext{
10 I want to thank Elan Lazuardi for holding a discussion with colleagues at University of Gadjah Mada (UGM) in order to further clarify the meaning of the term sosialisasi for this paper (Lazuardi, personal communication, 21 November 2013).

The textbook is written in Bahasa Indonesia; the translations into English are my own.
} 
term for the realm of governance. The term sosialisasi was commonly used in the 199os to refer to training the poor and transforming their behaviour. ${ }^{12}$ Dozens of reports were produced regarding the 'sosialisasi of poor neighbourhoods' in South Sulawesi (Hamid et al., 1987), Yogyakarta (Salamun 1993) and Padang (Sumarsono 1987). Reports on the socialization of politics in schools and villages also appeared (Sumarno 1992; Yusrizal and Nurharmi 1997). In addition to reports, municipal governments carried out projects and programmes to 'control' and change the behaviours of groups such as street traders. The mayor of Yogyakarta from 1986 to 1991 described how the government used to socialize the street vendors. He said:

One time we socialized them. I let them know that there is a place for dirty water and a filter, and that the leftover food should enter the filter and the water would fall back into the bucket. Then the water could be disposed of later and would not carry garbage with it such as plastic.... I was very upset if I saw people throw away plastic. They were not aware so we clarified (jelaskan) it to them.

personal communication, 2007

During the New Order era, government practices of sosialisasi thus focused particularly on changing the behaviours of marginal groups and the poor, who were perceived to be ignorant or uneducated. For traders, this could include providing information about topics such as how to cook food hygienically or how to throw away garbage.

Despite this paternalistic connotation, the term sosialisasi surprisingly continues to be widely used since the transition to democracy and considered part of democratic practice. NGOs, university students who do kuliah kerja nyata (voluntary placements in rural areas), government officials and community members all regularly use the term (Lazuardi, personal communication, 21 November 2013). As a Human Rights Watch report (2002:32) notes, sosialisasi refers to a 'practice of disseminating information from the top through community leaders or mass communication'. A company called IndoAdvisors understands sosialisasi as necessary for any business project to be successful. Their website reads:

Developing good working relationships with local groups and agencies can be critical to the success of foreign companies' operations in Indonesia. This service, which is known here as 'Sosialisasi' (Socialization),

12 The term sosialisasi was commonly used alongside other terms such as penyuluhan (counselling). 
is in greater demand as more foreign companies become involved in industries related to natural resources. [...] A comprehensive 'sosialisasi' programme should make communities aware of the project's goals and ensure that stakeholders understand their respective roles and responsibilities. This is particularly essential to the success of any rural-based project, whether land or marine based.

SOSIALISASI, n.d.

In the business environment it thus refers to informing stakeholders about a project rather than necessarily obtaining their input.

Sosialisasi also appears in newspapers to refer to how government, legislation, or other institutions are communicating with communities about new programmes or issues such as healthcare, the effects of drugs, or electoral processes (Kementerian Perhubungan Republik Indonesia, n.d.). The term sosialisasi is changing its meaning, however. In 2008 the Freedom of Information Act was enacted which stipulates that public offices such as the police have a responsibility to regularly provide information to the public (Basorie 2011). ${ }^{13}$ Sosialisasi is now commonly used to suggest that the government or institutions have not communicated sufficiently about a new project or topic. A legislative member of commission B in Jakarta praised the government's plan to develop an electronic road pricing system but criticized them for not socializing the community (kurang disosialisasikan) (Kuwado 2013). Evident in all these discussions is that socialization is still sometimes about transforming behaviours but is also now about transparent communication being good in and of itself.

\section{A Street Vendor Relocation: Working with 'Civil Society'}

In the mid-199os, few traders could be found selling on Mangkubumi Street, a main street of Yogyakarta City lined with shops. But after the economic crisis of 1997, the number increased exponentially. With few formal sector jobs available, Mangkubumi Street had transformed by 2006 into a bustling night market with over three hundred vendors selling from seven to ten in the evening. ${ }^{14}$ Female vendors were a rarity on Mangkubumi Street, and the majority of

\footnotetext{
13 In 2010, a network of information advocacy groups found that nearly half of their requests were denied when they asked for information regarding local budgets, laws and bylaws, or legal cases (Basorie 2011).

14 It was estimated that the amount of money circulating on Mangkubumi Street was 47,995,00o rupiah (5,523 Canadian dollar) per day, with cell phone sellers contributing half at 22,80o,0oo rupiah.
} 
customers were men buying a wide array of goods such as shoes, shirts, jeans, and used cell phones. The large number of used cell phones and other secondhand goods sold there contributed to the night market's nickname, pasar maling, or the thieves' market. The shop owners on Mangkubumi Street, many of whom were of Chinese descent, found the night market troublesome. Although the majority of their shops were closed by the time the traders set up their wares in the evenings, many shop owners lived above their businesses and found it difficult to enter or leave their homes at night by motorbike or car. The shops that remained open in the evening found that their customers were hesitant to visit and instead went elsewhere. Despite their discontent with the traders, however, the shop owners were not particularly vocal in public forums because they were afraid of causing a conflict or being attacked..$^{15}$

In October 2006, after the relocation plan was announced more widely, the traders were divided. One group, Pethikbumi, decided to oppose the relocation because they believed that the government had not included them in the decision-making and planning process. In their opinion, the municipal government was discriminating against them by moving them, but not other traders in the city. They were also deeply sceptical about relocations of street vendors to marketplaces in general, because they often caused traders to go bankrupt despite government promises that they would benefit or 'progress'. The majority of Pethikbumi traders were making relatively comfortable incomes on the street because their customer bases were strong. Starting over again at a new marketplace in another part of the city was not an attractive proposition.

Other groups with names like Independent, Aseme Gede and the Southern Square, supported the relocation and were optimistic about the plan. They felt that through this relocation they would obtain a 'free' location (or asset) in a marketplace and that their social and legal status would improve. Many of the Independent traders had lower incomes than the traders of Pethikbumi, and therefore had less at stake. Most of the Independent traders were also less optimistic that movements to oppose the government would succeed.

Once the Pethikbumi traders decided to refuse the relocation, they looked to other groups to provide them with support. They approached the Human Rights Protection Agency (Badan Pelindung Hak Kemanusiaan, BPHк), which was a well-known legal aid organization in Yogyakarta City, and the Indonesian Youth Movement for Change (Pergerakan Pemuda Indonesia untuk Perubahan, P PIP),

15 Even six years after the relocation, some shop owners remained hesitant about voicing their opinions openly. This response must be understood in relation to the history of Chinese in Indonesia and recent events during the fall of Suharto (see Purdey 2006; Strassler 2004). 
a community organization that had a strong base of university students. BPHK connected the Pethikbumi traders with a network of NGOs, which also provided them with advocacy advice. The NGO Network is a pro-democracy alliance composed of different organizations from across Yogyakarta City. ${ }^{16}$

B P H K was formed in 1999 to provide legal counsel to the poor and marginalized. They support various groups such as factory workers, women survivors of violence and street vendors. Most street vendor leaders in the city knew Marini, the director of в Рнк, because she has been the public face of advocacy for groups of street vendors across the city. She was known for her ability to effectively communicate traders' concerns to the government in writing and through legal channels.

Reflecting on how the rights of street traders had changed in recent years, Marini explained, 'Before Reformasi, street vendors generally accepted [government projects]. I mean that whatever the government did, they considered themselves powerless. But since Reformasi, they believe they have the right to receive information.' Marini had taken up an important role in the postauthoritarian era, because she could help street vendors draft various requests to the municipal government and formulate arguments based on the law (вРнк, personal communication, 16 July 2013).

PPIP is a student-based organization that formed in 2001 in order to advocate for the democratic rights of the rakyat kecil (small people), a morally loaded term referring to people with little money or power. In March 2000, activists gathered in Yogyakarta to write a political manifesto for the organization and to discuss how theories of revolution could be put into practice. The PPIP manifesto states that it considers the position of its movement, organization and ideological struggle as a cultural strategy to respond to people's suffering and to deal with exploitation and oppression. (Manifesto Politik 2001). PPIP had a strong network of university students who were willing to show up for protests and were interested in writing press releases that challenged capitalism and the growing inequalities between the rich and the poor. Iskander, a university student studying international politics, had joined PPIP in 2004 and called himself a supporter (pendamping) of Pethikbumi. He explained why PPIP decided to help support Pethikbumi:

We at P PIP supported our friends of Pethikbumi at the time of the relocation because we wanted to develop a movement against the forces from

16 This chapter focuses primarily on вPнК and PPIP because the NGO Network played a secondary role. They helped to run meetings. 
the government our friends were facing.... They were invited to talk about moving, not to talk about whether or not moving was best. They invited them to talk, but told them to move. In my opinion, we helped Pethikbumi to refuse because they were only given one choice, that is to move.

ISKANDER, personal communication, 1 August 2013

Adang, the secretary of Pethikbumi, had been selling second-hand shoes on Mangkubumi Street since 2004. From his perspective, the traders themselves had the power to withstand relocation without the help of these outside groups. To be effective in the post-authoritarian era, they knew they had to use demonstrations and legal channels. Political channels were important, but as the traders and their supporters described in several meetings, they could not trust political parties even though they tried to build alliances with them. For instance, Toni from the NGO network said at a meeting, 'don't believe political parties because they are also bought. The difference between them giving information and them giving the right information is very significant' (ВРн К, personal communication, 25 October 2007). In another meeting, the traders and their supporters noted that despite what the leader of the legislature had said to them, they would have to cross-check the information because there was no guarantee that he would act as promised (NGO network, personal communication, September 2008).

Despite the belief that they could organize on their own, Adang explained that the traders wanted to make sure their advocacy was in done in a systematic fashion. As a result, they approached BPHK and PPIP for help. Adang said:

Our leaders were able, we knew the process. But for the technical side of things [we needed help]. If we wanted to subpoena, or report to a different organization within the region or things like that, we did not understand [the process] at the time.

ADANG, personal communication, 15 July 2013

Despite Adang's initial perception that they did not need outside support, the lawyers from в Рнк felt that groups like traders needed their support because otherwise the government would not answer their written requests. Pethikbumi had sent multiple letters to the municipal government without a response. In Marini's opinion the government was more likely to respond to BPH K's letters because they were an institution. Marini's husband, who also worked for вPнк, continued the conversation by suggesting that not answering the street vendor letters was perhaps a 'conflict strategy' of the government in order to force them to look for outside support. He said that perhaps the government 
wanted the traders to convert their grievances into a legal case because that was much safer than demonstrations and anarchy. Marini also noted that, it is not only street vendors but also factory organizations and community organizations. None of their letters have been answered.' She thought that perhaps the government was not familiar with these groups, but it was more likely that once these groups had the support of a legal aid organization, the government would know they were serious and respond (BРнК, personal communication, 16 July 2013).

In the post-authoritarian era, the avenues and means for negotiating evictions and relocations are changing. More groups of traders are partnering with NGOs, community organizations and legal aid organizations in order to fight relocations, and to advocate for their rights through these legal and formal channels. Although some of these traders groups have the capacity to advocate on their own, it is often through working with outside organizations that the street vendors gain recognition as members of civil society and obtain responses from the government (cf. Chatterjee 2004).

\section{Sosialisasi during a Relocation Project}

In the post-Suharto era, municipal governments have become more concerned with the socialization process because the possibility of encountering resistance is greater. This concern over possible resistance was recognized in early government reports (Pemerintah Kota Yogyakarta 2004:IV-2). During my fieldwork the strategy of socialization by government officials was often described as a process of 'getting close' to the various stakeholders. This meant spending time with traders and community members who would be affected by the process. In an interview, Mayor Herry Zudianto described his sosialisasi strategy as involving 'speaking in their language', meaning that he did not speak in the language of bureaucracy. He also approached the traders in places where they felt comfortable, like at a food stall rather than a stuffy office. He proudly told the story about how he had invited them to his private home in order to make them feel welcome, following the Javanese philosophy witing tresno jalaran soko kulino - the idea that love/respect grows through familiar or frequent communication (H. Zudianto, personal communication, June 2008).

The mayor did not meet with the traders often enough, however, and this was part of Pethikbumi's frustration with the socialization process. They argued that it was difficult to access him, and held a protest demanding that they meet with the mayor directly. Lower level government officials were largely responsible for socializing the project, but these officials were perceived 
as having little power to actually change the project (the traders had hoped that instead of being relocated they could be allowed to stay and instead be re-organized on Mangkubumi Street). ${ }^{17}$ A government official whom I interviewed described how important the socialization process was because there was often resistance. He said:

Actually by the year 2006 the project could have been implemented, but [it was delayed] because there were lots of interests at play from political leaders and people, and because the sellers did not agree. Finally, we needed to convince them that if they sell there [in Pasar Kuncen] they will sell more than in the old place. So we had to get close to them, to learn to speak their language so that they can understand us. And that is a long process.

Government Office of the Environment, personal communication,

6 February 2008

This process of 'getting close' to the traders involved the lower level government officials setting up regular meetings with the traders. Two main municipal government officials were in communication with the Pethikbumi leaders on a regular basis. Ari, the head of the Office for Cooperation and Industry (Dinas Perindustrian Perdagangan dan Koperasi), had previously worked at the Regional Planning Board (Badan Perencanaan Pembangunan Daerah). He was known for his ability to calmly speak and reason with people. Galang was the head of the Marketplace Service (Dinas Pasar) in the city, and was described by the traders as 'well connected' since he ran his own religious school (pesantren) outside of the city. Ari and Galang had both been involved in previous relocations, and had successfully managed to relocate traders even when there was resistance.

On a number of different occasions the Relocation Team of government officials came to the street at 10:30 p.m. to meet with the traders. They sat on straw mats on the sidewalk alongside the traders and chatted for hours. An important aspect of these meetings was making the traders feel like they had access to the officials, and that at some point in the future they might be able to contact them for help. One trader from the Independent group invited the

17 Pethikbumi held demonstrations demanding to meet directly with the mayor because they hoped that by meeting with him face-to-face he might be willing to reconsider the project. Largely inaccessible for months during the project, the mayor in the end did meet with the traders, but by then they felt that they had little choice but to accept the relocation. 
various government officials, including the mayor, to his daughter's wedding (the mayor did not attend), perhaps to illustrate to his family and community that he had connections with the government.

Besides 'getting close' to the traders, socialization was also seen as an attempt to show the traders how sincere the government was. In the meeting mediated by the Regional Ombudsman Office, Ari said, 'We really truly believe in economically empowering the people. If we are talking about Cokroaminoto Street [where Kuncen Marketplace was located], I think in two or three years' time it will be an area of rapid growth and development and will become a premium area.' Galang, following Ari, also explained that the government wanted to empower the traders, which was why the traders would not have to pay retribution for the first six months in the new marketplace, and after that, they would only have to pay a small amount. 'The government is giving a big subsidy to the community for the economic empowerment of the people. That is what the government is really like,' Galang explained (Regional Ombudsman Office, personal communication, 11 September 2007). In the marketplace the traders would pay a retribution fee daily only after six months. Prior to the relocation the traders did not have to pay any 'rent' or 'retribution' fee to the government; they merely paid membership fees to the trader organization and for their use of electricity. The Pethikbumi leaders declared that they were ready and willing to pay a fee to the government for selling on Mangkubumi Street.

For Galang and Ari, sosialisasi was also a selling job. Galang described what he thought the process of sosialisasi involved during a meeting with an Ombudsman organization:

It is like I am a salesperson and I am going to tell you about a product that is good. If you drink this you will be strong. Whether a prospective buyer wantsit or not is anotherissue. If we used a method that was not acceptable, then that would be a problem. Otherwise, let the process continue. We are consulting [with the traders] either informally or formally, and will do this more intensively in the coming months as we approach the end of October.... Weneed to continue because lots [of traders] still do not understand.

GALANG, personal communication, 11 September 2007

Government officials most often explained the resistance to the relocation as a lack of understanding. With more socialization the traders would change their minds, they believed, and therefore the government's job was to sell this project to them. This idea of sosialisasi as selling appears in the Post-Suharto era in reports such as the Socialization of Halal Products with Provincial Sumbar Civil Servants (Yenrina, n.d.). The mayor also described to me during an interview 
how sosialisasi was like selling a product. He described what he said to the traders, 'Please go ahead and compare the promise I have made you with the promise made by the NGOs. Which one is more logical? If [the promise] is not realized, is it easier to prosecute the NGOs or me?' 'So I influenced them by asking, which is more rational? It was like selling a product' (H. Zudianto, personal communication, June 2008).

Whereas to the officials, sosialisasi was a sales pitch, to the Pethikbumi traders it was a process that should involve the exchange of documents, and a meaningful, two-way communication before the plans were made. The new Pethikbumi leaders who took power in November 2006 argued that they had not received enough socialization, more particularly that the government had not provided them with a clear concept of the relocation plan in writing. Like the government had feared, Pethikbumi publically announced that they were 'refusing the relocation' in January 2007, and they organized a handful of demonstrations, high-level meetings, and press events. They critiqued the fact that the government had not met with them often enough, and had yet to provide any concrete plan in writing. One of the new leaders of Pethikbumi explained, 'We had a principle: We thought that if the government wants to promise us this, it must be written down.... It must be written in black and white...' (Adang, personal communication, 14 August 2013).

Besides taking the municipal government to task for not giving them the plan in writing, they also criticized a regulation affecting the relocation that did appear in writing without their knowledge or input. In July 2007, Pethikbumi learned that a new regulation that would officially make selling on Mangkubumi Street illegal had been drafted without their knowledge (Perda No. 45, 2007). Prior to this time, they did not have official permits, but there was no written regulation banning them from selling either. This new regulation would give the government the legal authority it needed to relocate the traders in the upcoming months. Pethikbumi and its supporters argued that it was illegal for the government to produce this document without prior sosialisasi since new legislation required the government to consult with groups it impacted. As a result, five members of Pethikbumi took the mayor to court for breaking the law. After holding a protest outside of the courts, it was written in the newspaper, 'the traders feel that the regulation breaks the law because it was done without a process of rationalization and socialization. The reason for the programme is to make the area green (taman), but from their [the traders] perspective it is only to evict traders' ('Sidang Gugat' 2007).

To the discomfort of the government officials, the traders and their supporters requested the involvement of a third party in the sosialisasi process. After filing the court case, Pethikbumi supporters' recommended that they write to 
the Provincial Ombudsman (Lembaga Ombudsman Daerah or LOD) about their case and request that the ombudsman both investigates and acts as a mediator for their case. In September 2007, the ombudsman brought Pethikbumi and the government Relocation Team together to facilitate the sosialisasi process. In these meetings, Pethikbumi criticized the government for not giving them written copies of the relocation concept in a timely fashion, for not listening to their plan that proposed regulating the trade on Mangkubumi Street instead of relocating the traders, and for producing this regulation without consulting them. Asked to respond, the two main government officials, Ari and Galang, both argued that they were currently in the process of socializing and that they were planning to intensify their communication with Pethikbumi. Ari argued, however, that the government developed the regulation without consultation because it was a technical matter, an area that required specific expertise.

This new mediator thus forced the government to justify and explain its approach to socialization ('Pemkot Sebar' 2007). ${ }^{18}$ The officials responded to these criticisms by arguing that they were in the middle of the sosialiasi process. The idea that they were holding the meetings, or socializing, with the traders was often more important than what actually happened or was discussed in the meetings. In many of the meetings I attended, the municipal government promised the traders that there would be more meetings and opportunity of socialization, deferring the process of agreement or understanding to some future date.

Although Pethikbumi was pushing the boundaries of sosialisasi, the organization had their own problems of sosialisasi with its members. Pethikbumi leaders too were expected to inform and consult with their members about their activities. But it did happen that sometimes the leaders told them versions of the truth that were convenient to themselves. This practice, strikingly, was not discouraged by one of their NGO partners, who said in a meeting, 'I hope that our friends that are here will really promise to socialize (mensosialisasikan), ${ }^{19}$ and give the members information about what we have

18 Following the facilitation of two meetings, the ombudsman generated a series of recommendations, including the idea that the municipal government should reconsider its plans in order to recognize Pethikbumi, and that the municipal government should carry out intensive communication in order to create a win-win solution. They also recommended that the new regulation (Perwal No. 45 2007) should be postponed until Pethikbumi and the government could see eye to eye on the matter.

This is the transitive verb for socializing in Bahasa Indonesia. 
spoken about this evening. But you do not need to share things that might scare them' (NGO Network, personal communication, September 2007). ${ }^{20}$

During internal Pethikbumi meetings, the leaders increasingly placed pressure on their members. Often in these meetings a discourse of 'traitor' (pengkhianat) and 'enemy' (musuh) was used to describe those who had decided to switch sides and support the relocation. In one late night meeting a leader said: 'I am here asking for you to stay strong and not to become a traitor and to defend Mangkubumi Street with everything (mati-matian)' (Pethikbumi, personal communication, 6 November 2007). The Pethikbumi leaders also threatened their members, warning that if they joined the relocation they would not be given a selling location on Mangkubumi. As Aspinall and Weiss (2012:14) suggest, civil society can be a place for the 'reproduction of social inequality as it is a site from which that inequality is challenged'.

Despite recommendations from the ombudsman and the court case against the mayor, the relocation project went ahead as planned with only a short delay of ten days. The traders refusing the relocation increasingly feared that they might be left with nothing if they did not quickly join the relocation. The government also banned them from selling on Mangkubumi and placed two kinds of police on the street to keep traders from returning to Mangkubumi. ${ }^{21}$ With little hope left and no income, the Pethikbumi leaders finally decided to accept the relocation. In exchange for being allowed to join the relocation they were forced to drop the court case. ${ }^{22}$ In the days before Pethikbumi's members entered the marketplace, the mayor announced that the traders had not wanted to move because they had not understood. As a result, they should not be viewed as enemies. When they finally agreed to the relocation, the project was taken as a success; the conflict had been resolved because now they 'understood' as the result of the government's successful socialization process. (Pemerintah Kota Yogyakarta 2007).

In March 2014, a couple ex-Pethikbumi traders were asked to reflect on the term sosialisasi and its use during the relocation. They compared the process of sosialisasi during the relocation to the approach used during elections

20 The NGOs, legal aid organization and university student supporters were concerned that Pethikbumi's leaders were not socializing enough with the members, and that they were resembling their predecessors by acting on their own will, based on imagined support they actually might not have.

21 They were police from Potables (Kepolisian Kota Besar, the Central Police Department, Yogyakarta) and Satpol pP (Satpol Pamong Praja, Public Order police), the latter of which is responsible for overseeing the laws related to the city.

22 The group submitted an official document to the courts withdrawing the case (10/ PENTUN/2007/PTUNYK). 
(sosialisasi pemilu). ${ }^{23}$ According to them, sosialisasipemilu (and other kinds of sosialisasi especially those used in agricultural projects) is a technical necessity to make sure the 'people' (rakyat) know what to do during the election. However, for issues that involve their livelihoods like on Mangkubumi Street, the meaning of sosialisasi should not stop at informing (pemberitahuan). To pass a new regulation, the government needs to undertake sosialisasi with various stakeholders. The process of sosialisasi in this case meant a process of discussion and dialogue between all the parties involved. Joko said that sosialisasi is not important to him if the policy (kebijakan) has already been passed. This was different from what happened in 2012, when the municipal government attempted to pass a regulation on marketplaces in the city (Draft Regulation on Marketplaces or Rancangan Peraturan Daerah tentang Pasar). In the formulation of the regulation, they did a 'uji materi' (judicial review) and invited representatives from each market. Joko was sent as representative from Kuncen Marketplace. However, in 2014 he still had not heard what was happening with the regulation.

Reflecting on the emergence of the municipal regulation (Perwal No. 45) back in 2007, Joko said that the state acted as if it had more knowledge about the best solution for the city, while the traders were not fully involved. He again called it 'demokrasi semu' (fake democracy), and explained that democracy should mean partisipasi rakyat (the participation of the people), but what had happened was a mere false/pseudo-participation (partisipasi semu). With farmers, for example, Suharto's regime used the term penyuluhan or counselling often. It is still used now, but usually only in agriculture, whereas in the city sosialisasi is used more widely. According to Joko, the term sosialisasi is still being used in a manner more or less similar to the way it was used during the New Order era. ${ }^{24}$

\section{Conclusion}

Pethikbumi had many reasons for refusing the relocation. They believed that they should not have been asked to relocate, as traders from other areas had not been asked, that relocations often fail to improve the livelihoods of traders,

\footnotetext{
23 I want to thank Elan Lauzardi for collecting this data on 5 March 2014, in Kuncen Marketplace.

24 Joko said that the main difference with the New Order was that people who resisted or rejected the government's plan during the New Order were likely to be kidnapped, jailed or even killed, or simply disappeared, while since the Reformasi, they could be evicted or threatened by thugs. In his opinion, this was more or less the same.
} 
and that the government had waited too long before banning them from selling. These concerns were not about the law. The argument that the government had failed to properly socialize the traders about this project positioned the traders alongside other citizens in Indonesia who now had the right to be informed and consulted. The term sosialisasi, a concept and practice from the New Order, was now being considered a right rather than a benefit the government might provide to the population. Moreover, the term took on new meanings through its usage by citizens and government officials, who were deploying the term to their own, different, ends. However, as examples above have shown, the discourse on sosialisasi, or perhaps more accurately, the results of the usage of this term, might not be as novel as those involved in the relocation imagined.

In the introduction to this book, Berenschot, Schulte Nordholt and Bakker (2017) argue that citizenship studies have often paid far too little attention to the form that democratic citizenship takes in non-Western states. They argue that the concept of individualistic and independent citizens has not had much currency in Southeast Asia, and that there is a need to study what democratic citizenship looks like on an everyday basis in places like Indonesia. This chapter has sought to show the impact that democratic reforms are having on Suharto-era, established forms of state - citizen interactions. The case that I have presented here illustrates that groups such as street vendors are working with legal aid and community organizations to widen the public sphere, and are using sosialisasi, a term from the New Order period, as a central means to engage in a more active defence of citizen rights.

The Pethikbumi traders who joined the relocation perceived the government's process of sosialisasi to be similar to the New Order period. It involved face-to-face communication with the traders listening to the government's plans. Although they met with government officials numerous times, in the end they were essentially forced to follow the government's proposal. Unlike during the New Order period, however, the traders had access to a number of new resources, which made the government's job much more difficult. First, the traders had access to a series of civil society organizations that helped them formulate and make demands in relation to the law. Although the traders might have been illegal, they still had rights as citizens to be properly consulted. Second, their supporters helped them to access institutions such as the court and an ombudsman organization. Channelling their resistance through these institutions gave the traders' claims greater legitimacy. Rather than trying to claim their rights through back-door deals, the traders thus sought to use new laws passed since Reformasi to formally challenge the project.

From the perspective of the government officials, their socialization process was a success: they eventually relocated the traders as planned. The discourse 
of sosialisasi can, on one level, be read as a legitimizing strategy used by the government to justify how they carried out the relocation by saying that they consulted with the traders. It can be further viewed as creating an image of participation documented in so many development projects around the world (Mosse 2005; Sivaramakrishnan 2008). However, it appears to be a continuation of the New Order practice in which the government and interested parties carried forward projects, claiming to have consulted with the stakeholders, when in reality they simply used socialization to persuade those stakeholders to agree with their own viewpoint. From my observation of these sosialisasi meetings the government was often more concerned with holding them, and saying they had met with the traders, rather than really dealing with any of the traders' concerns substantially. It was different in the sense that the government officials were under greater pressure from the public, NGOs and the traders to meet with the latter and socialize this project, than they would have been during the New Order period.

Unlike in the past, there is a new group of middle-class activists willing to help marginalized groups, and a new set of institutions through which their grievances can be voiced. In a certain way, the traders became clients of the activists, and mobilized these relations to effectively communicate their rights. These relationships are informal but legal, and suggest that street vendors are considered as members of civil society in certain contexts (see Chatterjee 2004). In the Reformasi era, street vendors are attaching new democratic expectations to the term sosialisasi. They are using this term to make claims for more transparency and information as well as a more meaningful consultation process when it comes to government plans that impact their livelihoods. Yet, despite their expectations for the municipal government's practices of sosialisasi to change, at various moments they also imitated some of the very practices when dealing with internal dissent. Finally, sosialisasi can be considered a 'halus' or soft way of protesting; by saying that the plan had not been socialized the traders avoided saying in a direct manner that they opposed the relocation plan. Such a use of the term thus avoids an adversial approach.

\section{References}

Afifah, R. (2012, April 1). Ngobrol dengan PKL, Jokowi Janji Tak Ada Pengguran. Kompas. Retrieved from http://www.kompas.com.

Aspinall, E. (2013). A nation in fragments: Patronage and neoliberalism in contemporary Indonesia. Critical Asian Studies, 45(1), 27-54.

Aspinall, E., \& van Klinken, G. (2011). The state and illegality in Indonesia. Leiden: KITLV Press. 
Aspinall, E., \& Weiss, M. (2012). The limits of civil society: Social movements and political parties in Southeast Asia. In R. Robinson (Ed.), Routledge handbookfor Southeast Asian politics (pp. 213-228). New York: Routledge.

Bangun, A. (1994). Sejarah Berdirinya Koperasi Tri Dharma, Persatuan Pedagang Pinggir Jalan Yogyakarta [History of the establishment of Tri Dharma Cooperative in Yogyakarta, Roadside Traders Association]. Yogyakarta.

Barker, J. (1998). State of fear: Controlling the criminal contagion in Suharto's New Order. Indonesia, 66, 7-43.

Barker, J. (2006). Vigilantes and the state. Social Analysis, 5o(1), 203-207.

Barker, J. (2009). Negara beling: Street-level authority in an Indonesian slum. In G. van Klinken \& J. Barker (Eds.), State of authority: The state in society in Indonesia (pp. 47-72). Ithaca, NY: Cornell Southeast Asia Program Publications.

Barker, J., \& van Klinken, G. (2009). Reflections on the state in Indonesia. In G. van Klinken \& J. Barker (Eds.), State of authority: The state in society in Indonesia (pp. 17-45). Ithaca, NY: Cornell Southeast Asia Program Publications.

Basorie, W.D. (2011, April 28). Indonesia Freedom of Information law's [sic], one year on. The Jakarta Post. Retrieved from http://www.thejakartapost.com.

Berenschot, W., Schulte Nordholt, H. \& Bakker, L. (2017) Citizenship and Democratization in Postcolonial Southeast Asia. In: W. Berenschot, H. Schulte Nordholt, \& L. Bakker (Eds.) Citizenship and Democratization in Southeast Asia (pp. 1-32). Leiden: Brill Publishers.

Chatterjee, P. (2004). The politics of the governed: Reflections on popular politics in most of the world. New York: Columbia University Press.

CV. AKA (Konsultan Perencana dan Pengawas Bangunan). (2005). Laporan akhir: Kegiatan rancang bangun asset daerah, pekerjaan penyusunan (FS) eks Pasar Kuncen [Final report: Regional assets building design activities, compiling work for exKuncen Market]. Yogyakarta.

Dinas Pasar Yogyakarta. (2013). Pasar Klithikan Pakuncen: Pusatnya klithikan Yogyakarta. Profile pasar tradisional kelas 2 dan kelas 3 Kota Yogyakarta [Kuncen Second-hand Marketplace: Yogyakarta's Centre for Second-hand Merchandise. Profiles of class 2 and class 3 traditional marketplaces in Yogyakarta City]. Yogyakarta, Indonesia.

Dipa, A. (2012, January 18). Bandung to regulate street vendors. The Jakarta Post. Retrieved from http://www.thejakartapost.com.

Dwi, S. (2013, November 14). Over 800 street vendors relocated. The Jakarta Post. Retrieved from http://www.thejakartapost.com.

Education for a civil society. (1999, October 9). The Jakarta Post. Retrieved from http:// www.thejakartapost.com.

Ford, M. (2009). Workers and intellectuals: NGOs, trade unions and the Indonesian labour movement. Singapore: NUS Press.

Gibbings, S. (2013). Unseen powers and democratic detectives: Street vendors in an Indonesian city. City \& Society, 25(2), 235-259. doi: 10.1111/ciso.12018. 
Gugatan TUN Perawal No. 45 Tahun 2007. (2007, October 10). Badan Pelindung Hak Kemanusiaan.

Gupta, A. (2012). Red tape: Bureaucracy, structural violence, and poverty in India. Durham: Duke University Press.

Hadiwinata, B. (2004). The politics of NGOs in Indonesia: Development democracy and managing a movement. London: Routledge.

Hamid, A., Suprapti, M., \& Bale, D. (1987). Sosialisasi pada perkampungan miskin daerah Sulawesi Selatan [Socialization in poor neighbourhoods of South Sulawesi]. Sulawasi, Indonesia: Departemen Pendidikan dan Kebudayaan, Proyek Inventarisasi dan Dokumentasi Kebudayaan Daerah.

Hammado, T. (1979). Sektor informal diJakarta [The informal sector in Jakarta]. Jakarta, Indonesia: Universitas Indonesia, Pusat Latihan Penelitian Ilmu Ilmu Sosial Jakarta.

Hansen, T.B., \& Stepputat, F. (2001). States of imagination: Ethnographic explorations of the postcolonial state. Durham, NC: Duke University Press.

Hill, D. (2006). The press in New Order Indonesia. Jakarta: Equinox Publishing.

Holston, J. (2008). Insurgent citizenship: Disjunctions of democracy and modernity in Brazil. Princeton, NJ: Princeton University Press.

Human Rights Watch. (2002, December). Breakdown: Four years of communal violence in Central Sulawesi. Indonesia, 14(9)(C). Retrieved from https://www.hrw.org/ reports/2002/indonesia/indonesian102.pdf.

Humphrey, C. (2004). Sovereignty. In D. Nugent \& J. Vincent (Eds.), A companion to the anthropology of politics (pp. 418-436). Malden, MA: Blackwell Publications.

Ichsan, M. (1982). Sebab-sebab timbulnya pedagang kakilima dan usaha-usaha penanggulangannya [The causes of the emergence of street vendors and the efforts to address it]. Malang: Malang Universitas Brawijaya, Direktorat Jendral Pendidikan Tinggal Departemen Pendidikan dan Kebudayaan.

Janowitz, M. (1975). Sociological theory and social control. American Journal of Sociology, 81(1), 82-108. doi: 10.1086/226035.

Jellinek, L. (1991). The wheel of fortune: The history of a poor community in Jakarta. Sydney: Asian Studies Association of Australia in Association with Allen and Unwin.

Jessup, H. (1985). Dutch architectural visions of the Indonesian tradition. Mugarnas, $3,138-161$.

Kementerian Perhubungan Republik Indonesia. (n.d.). Sosialisasi program retrukturisasi angkutan umum massal. Retrieved from http://m.dephub.go.id/read/kolom -redaksi/sosialisasi-program-retrukturisasi-angkutan-umum-massal-15112.

Konsep Pasar Klithikan Dinilai Kurang Jelas: Tolak Relokasi, Pethikbumi Datangi Dewan. (2007, March 17). Kedaulatan Rakyat, p. 2.

Kusno, A. (2005). The significance of appearance in the Zaman Normal, 1927-1942. In F. Colombijn, M. Barwegen, P. Basundoro, \& J.A. Khusyairi (Eds.), Kota lama, kota baru: Sejarah kota-kota di Indonesia sebelum dan setelah kemerdekaan 
[Old city, new city: The history of the Indonesian city before and after independence] (pp. 493-521). Yogyakarta, Indonesia: Ombak Press.

Kuwado, F. (2013, November 20). Dukung ERP, Anggota DPRD DKI Inginkan Adanya Sosialisasi. Kompas. Retrieved from http://www.kompas.com.

Liu, H. (2012, March 8). Presiden tak senang kaki lima digusur. Kompas. Retrieved from http://www.kompas.com.

Lund, C. (2011). Fragmented sovereignty: Land reform and dispossession in Laos. The Journal of Peasant Studies, 38(4), 885-905. doi: 10.1080/03066150.2011.607709.

Manifesto Politik. (2001). Pergerakan Pemuda Indonesia untuk Perubahan. Yogyakarta, Indonesia.

Maryati, K., \& Suryawati, J. (2006). Sosiologi untuk SMA and MA kelas X. Jakarta, Indonesia. PT. Gelora Aksara Pratama.

Masalah pedagang kaki lima di kodya Bandung dan penertibannya melalui operasi Tibum [The problem of street vendors in Bandung muncipality and their ordering through the opertion of Tibum] (1980). Bandung, Indonesia: Universitas Katolik Parahyangan.

Massa, M. (2013, March 23). Hatta Radjasa: Negara Melindungi PKL. Kompas. Retrieved from http://www.kompas.com.

Mosse, D. (2005). Cultivating development: An ethnography of aid policy and practice. London: Pluto Press.

Nordholt, S. (2003). Renegotiating boundaries: Access, agency and identity in postSoeharto Indonesia. Bijdragen tot de Taal-, Land- en Volkenkunde, 159(4), 550-589.

Ong, A. (1999). Flexible citizenship: The cultural logics of transnationality. Durham, NC: Duke University Press.

Pemberton, J. (1994). On the subject of "Java." Ithaca, NY: Cornell University Press.

Pemerintah Kota Yogyakarta. (2007, November 13). Walikota Berharap Pasar Klithikan Membawa Berkah. Retrieved from http://www.jogjakota.go.id/index/extra.detail/ 1694/walikota-berharap-pasarklithikan- membawa-berkah.html.

Pemerintah Kota Yogyakarta, Kantor Pengendalian Dampak Lingkungan. (2004). Rencana pembangunan Pasar Kuncen [Kuncen Market development plan]. Yogyakarta, Indonesia.

Pemkot Sebar Surat Pemberitahuan Relokasi: Pethikbumi Lakukan Aksi, 10 Ribu Tanda Tangan. (2007, October 28). Kedaulatan Rakyat. Retrieved from http://www .ombudsman-asahan.org.

PT. CIPT Nindita Buana (2005). Laporan akhir: Rancang bangun eks Pasar Hewan Kuncen [Final report: Engineering/building design and construction of ex-Kuncen Livestock Market]. Yogyakarta.

Purdey, J. (2006). Anti-Chinese violence in Indonesia, 1996-1999. Honolulu: University of Hawai'i Press. 
Rajasa, H. (2013). Hatta Siap Lindungi PKL. Retrieved from http://hatta-rajasa.info/ $\mathrm{read} / 1504 /$ hatta-siap-lindungi-pkl.

Reerink, G. (2009). When money rules over voice: Regional autonomy and spatial planning in Bandung benefits the elite. Inside Indonesia, 98, October-December. Retrieved from http://www.insideindonesia.org.

Ryter, L. (2009). Their moment in the sun: The new Indonesian parliamentarians from the old OKP. In G. van Klinken \& J. Barker(Eds.), State of authority: The state in society in Indonesia (pp. 181-218). Ithaca, NY: Cornell Southeast Asia Program Publications.

Salamun, T. (1993). Sosialisasi pada perkampunganyang miskin di kota Yogyakarta [The socialization in poor neighbourhoods in the city of Yogyakarta]. Yogyakarta, Indonesia: Departemen Pendidikan dan Kebudayaan, Direktorat Jenderal Kebudayaan, Direktorat Sejarah dan Nilai Tradisional, Proyek Penelitian, Pengkajian dan Pembinaan Nilai-Nilai Budaya.

Satpol PP Tak Pakai Cara Kekerasan. (2012, October 31). Kompas. Retrieved from http:// www.kompas.com.

Sidang Gugat Wali Kota Ditunda, PKL Kecewa Dinilai Cacat Hukum. (2007, November 8). Suara Merdeka. Retrieved from http://www.suaramerdeka.com.

Simandjuntak, D. (2012). Gifts and promises: Patronage democracy in a decentralized Indonesia. European Journal of East Asian Studies, 11(1), 99-126.

Sinombor, S. (2008, March 1). Joko Widodo dan Misi Mengorangkan Wong Cilik. Kompas. Retrieved from http://www.kompas.com.

Sivaramakrishnan, K. (2008). Crafting the public sphere in the forests of West Bengal: Democracy, development and political action. American Ethnologist, 27(2), 431-461. doi: 10.1525/ae.2000.27.2.431.

Sosialisasi. (n.d.). In IndoAdvisors. Retrieved from http://www.indoadvisors.com/sosia lisasi.html.

Strassler, K. (2004). Gendered visibilities and the dream of transparency: The Chinese Indonesian rape debate in post-Suharto Indonesia. Gender and History, 16(4), 689-725. doi: 10.1111/j.0953-5233.2004.00361.x.

Sumarno. (1992). Peranan sekolah dalam proses sosialisasi politik: Studi pembinaan sikap dan kesadaran berbangsa bernegara siswa tingkat sekolan menengan sertã faktor-faktor yang mempengaruninya di wilayah Jawa Tengah dan Daerah Istimewa Yogyakarta: Laporan Penelitian [The role of schools in the process of political socialization: The study of attitudes and awareness toward the nation among middle school students and what affects them in Central Java and the Special Region of Yogyakarta: Research Report]. Yogyakarta, Indonesia: Fakultas Ilmu Pendidikan, Institut Keguruan dan Ilmu Pendidikan Yogyakarta.

Sumarsono, M. (1987). Sosialisasi pada perkampungan miskin (struktur keluarga dan sosialisasi) di Kotamadya Padang [Socialization in poor neighbourhoods (family 
structures and socialization) in the city of Padang]. Padang, Indonesia: Departemen Pendidikan dan Kebudayaan.

Telle, K. (2009). Dharma power: Searching for security in post-New Order Indonesia. Social Analysis, 53(1), 141-156. doi: 10.3167/sa.2009.530109.

Traders brace for eviction. (2008, January 17). The Jakarta Post. Retrieved from http:// www.thejakartapost.com.

Waworoentoe, W.J. (1975). Markets and communities in Jakarta and Bandung. Bandung: Institut Teknologi Bandung.

Yenrina, R. (n.d.). Sosialisasi Produk Halal Bersama Pegawai Pem-Prov Sumbar [Web $\log$ post]. Retrieved from http://www.halalmui.org/newMUI/index.php/main/ detil_page/8/1333.

Yusrizal \& Nurharmi. (1997). Sosialisasi politik masyarakat desa: Studi kasus di Desa Sunur Timur, Kecamatan Nansabaris: Laporan penelitian [Political socialization in rural communities: A case study in the village of East Sunur, Nansabaris District: Research report]. Fakultas Keguruan dan Ilmu Pendidikan, Lembaga Penelitian dan Pengabdian Masyarakat, Universitas Bung Hatta. 